\title{
The Correlation between the New Prostitution Acts and Sexually Transmitted Diseases in Korea*
}

\author{
Yoonseock Lee** and Youngjae Jung***
}

\begin{abstract}
The purpose of this study is to analyze the correlation between the New Prostitution Acts and the continuous increase in the numbers of sexually transmitted disease patients since their implementation in 2004, in addition to examining the change in the population of prostitution traders, and the trend toward new kinds of sex industries. The anti-prostitution law, which has the laudable goals of protecting sexual morality and human rights, also created unintended consequences, including interference with established methods of tracing sexually transmitted infections.
\end{abstract}

Keywords: new anti-prostitution law, unintended consequences, sexually transmitted disease.

In our age, with its passion for conscious control of everything, it may appear paradoxical to claim as a virtue that under one system we shall know less about the particular effect of the measures the state takes than would be true under most other systems and that a method of social control should be deemed superior because of our ignorance of its precise results.

- Friedrich August von Hayek, The Road to Serfdom, 1946

\footnotetext{
* An earlier version of this paper was presented at the Second International Conference of the Brain Korea 21, Graduate School of Public Administration, Seoul National University, November 21-22, 2007.

** Yoonseock Lee is currently a visiting researcher at Yokohama City University, Japan and a $\mathrm{Ph}$. D. candidate at the graduate school of public administration in Seoul National University.E-mail: yoonslee@paran.com

*** Correspondence Author. Youngjae Jung is a $\mathrm{Ph}$. D. candidate at the graduate school of public administration in Seoul National University. E-mail: heifetz@hanmail.net
}

Manuscript received June 2009; out for review July 2009; review completed August 2009; accepted August 2009.

The Korean Journal of Policy Studies, Vol. 24, No. 1, 111-125 (2009)

C 2009 by the GSPA, Seoul National University 


\section{INTRODUCTION}

It is often said that all policies go through a full cycle, "from formation, to implementation, to closure" (Lasswell 1971, 28-30). However, if one were to trace the history of past policies, one would discover that in fact only a few policies complete the full cycle. Most policies tend to cause a problem during implementation or even after their expiration, which results in another policy being formed to address the new issue. Therefore, often the start of a new policy is only the beginning of a chain of successive policies. In the case of Korea's recent real estate policy, enacted in 2006, the nine consecutive policies were not independent but a series of policies, each complementary to the ones implemented earlier. Consequently, the lack of one cohesive policy only served to discredit the government while failing to achieve the intended effect, which was the stabilization of real estate prices. Not only in this case, but also in other recent cases, we can find that most of the problems arising from a policy are based on the attempts of the policy itself to solve problems. In other words, it has been said, policy is its own cause (Wildavsky 1979).

Unanticipated or unintended consequences are situations where an action results in an outcome that does not match what was anticipated or intended (Lee 2007). The unintended results may be foreseeable or unforeseeable, but they should be the logical, or at least likely, results of the action (Merton 1936). Governments usually intervene in private-sector arrangements to correct problems that the private sector is unable to solve, or to accomplish specific public goals that rank highly on the government's policy agenda.

The Prevention of Prostitution and the Protection of Victims Act, and the Punishment for the Procuration of Prostitution Act (together referred to below as the New Prostitution Acts) were implemented on 23 September 2004. Their goals included the prevention of prostitution, the protection and support of prostitution victims and prostitutes, the abolition of prostitution and human trafficking, and the protection of the rights of prostitution victims. It is not clear, however, that these goals have been accomplished. Some evidence suggests that the New Prostitution Acts, rather than curbing prostitution, have led to an increase in the number of cases of sexually transmitted diseases (STDs), that a new kind of secret prostitution business has emerged to avoid crackdowns by the police, and that prostitution has even proliferated.

The purpose of this study is to analyze the correlation between the New Prostitution Acts and the continuous increase in the numbers of STD patients since the Acts' implementation, and to examine the change in the population of prostitution traders and the trend toward new kinds of sex industries. 


\section{HISTORICAL BACKGROUND}

\section{History of Prostitution and Argument for Abolition and Prohibition}

Prostitution is often called one of the oldest professions, and society has often made efforts to eliminate prostitution. Since Roman times, there have been various approaches by governments toward prostitution. Conservative governments have attempted to prohibit it, while more liberal governments have treated the prostitution trade as an important source of revenue. Prior to the emergence of feminism, "Christianity, which was the dominant ideology in western society, viewed prostitution as a sin" (Clarkson 1939) and as an epidemic (Conner 1989; Trumbach 1991), and it was treated accordingly. On the other hand, in the nineteenth century when laissez-faire (Richards 1979) became one of the main ideologies of western society, sex workers were given a free rein.

In Korea, until the nineteenth century, Confucianism was the dominant ideology (Park 1996), and prostitution was prohibited, so it did not emerge as a social problem at that time. However, after Korea gained independence and established its own government, the numbers of sex workers began to increase steadily, and this frequently raised social issues.

The recent debate in Korea about whether prostitution should be prohibited or legalized was concentrated mainly on the feminist viewpoint. Compared to men's economic opportunities, women's opportunities to conduct economic activities in growth areas in Korea was insignificant (Woo 2006). This was strongly influenced by Korea's Confucian tradition. "With all their severe poverty, a lot of women had no choice but to participate in prostitution and the rapid economic growth contributed to the prostitution market increasingly" (Lee 2003). For this reason, the term prostitution conveys the meaning of women's sacrifice in Korea.

The legal definition of prostitution in Korea states that men, as customers, buy women, as products; hence the prostitution problem converges on the issue of the sexual abuse of females by males. "In modern times, the viewpoint of the European states regarding the prostitution problem is to approach it on two fronts-abolitionism and regulation (some control by the state)" (Kivingston, Day, and Ward 2001). In the latter part of the twentieth century, many European states' policies concerning the commercial sex trade have tended toward abolitionism.

"A prostitute working in the commercial sex trade was generally considered not to be a voluntary worker but a victim" (Park 1996). Prostitution or commercial sex itsclf evokes a comparison with slavery. The principal aim of regulations and policies was to criminalize and punish those profiting from prostitution (namely the owners of broth- 
els, profiteers, agents, and managers). However, in most cases, "it is the sex workers that suffer as a result of the policies" (Lee 2006).

"Legalization in the nineteenth century was constructed in normative opposition to state regulation where prostitutes were registered for the purposes of monitoring sexually transmitted diseases (STDs) such as syphilis and gonorrhea, in an attempt to control and protect public well-being" (Kivingston, Day, and Ward 2001). Some regulations relating to prostitution were intended to deal with the commercial sex trade on a practical level, primarily through attempting to control the spread of STDs. Advocates for the legalization of prostitution took the position that it was wrong for the state to profit from or to overlook the commercial sex trade. "While feminists attacked the mechanism-such as patriarchic system and male supremacy, etc.-for making sex workers responsible for prostitution in general and sexually transmitted disease in particular" (Walkowitz 1980).

\section{Correlation between STDs and Prostitution}

Historically, one of the reasons that prompted the government to prohibit prostitution or manage it aggressively was to stop the diffusion of STDs. Unlike other contagious diseases, STDs are influenced by social factors as well as the behavior patterns of individuals. In a study by Shin and Kim (2001), 77.6 percent of men in the sample who contracted STDs were infected by a high-risk group. The study also found that the causes of STD infection before the New Prostitution Acts were as follows: " $38.3 \%$ from brothel prostitution; $18.9 \%$ from bar girls; and $20.6 \%$ from call girls. The remaining $20 \%$ was attributable to the spouse or the girl friend" (Shin and Kim 2001). Thus, Shin and Kim concluded that there is a direct correlation between the spread of STDs among men and the commercial sex trade.

Shin and Kim's study selected only men's data as the sample for their analysis. Women sex workers regularly undergo medical inspection by regional public health centers, which explains why women's STD data have regional variations by brothel areas and thus why they had difficulties in conducting scientific research using women's STD data. In addition, "the pathways of men's STD infections are more various than women's" (Shin and Kim 2001), and men tend to go to different clinics at random. Furthermore, men who have contracted STDs are usually examined and treated in public health centers or by urologists, while "women (excluding sex-workers) tend to be examined and treated for STDs by obstetrics or gynecology centers" (Choi et al. 2007). The Sentinel Surveillance, operated by the Korea Centers for Disease Control and Prevention, uses "data collected monthly from urologists and general hospitals to compile a report on the number of STD infections and the infection pathway" 
(Korea Centers for Disease Control and Prevention 2007). However, most obstetrics and gynecology centers do not have to submit their data for the report. As a result, the number of women STD patients cannot be counted accurately or estimated by the government except through monitoring sex workers. This means that the men's STD data will tend to be representative of random sampling, which provides a more scientific approach, and so the regional group data for men serve the purposes of this research better because they are more representative and less biased than the data for women.

\section{THE NEW PROSTITUTION ACTS}

\section{Characteristics}

The New Prostitution Acts prohibit all monetary forms of prostitution; this is called the principle of complete prohibition. The same principle was adopted in the Prostitution Act of 1961, but it seems that neither law has resulted in a decrease in prostitution.

As compared with the Prostitution Prevention Act (PPA),

The New Prostitution Acts protect women who practice prostitution by compulsion, strengthen the penalties against procurers of customers and create articles of economic sanctions that confiscate profits from mediation as well as impose additional criminal charges. In terms of criminal punishment against prostitution clients, the New Prostitution Acts are identical to the PPA. However in terms of the applicable law, while the clients would be freed after some admonition under the PPA, the clients would be strictly prosecuted under the New Prostitution Acts. (Kwon 2004)

As seen above, while the New Prostitution Acts take a typically regulatory position, European nations and other advanced nations have differed in their positions on prostitution at different times. Even within the feminist movement, opinions vary (Lee and Kim 2006; Outshoorn 2004; Willis 1984). Along the feminist spectrum, radical and liberal feminism are in distinct contrast. Radical feminism focuses on "the patriarchal family system" (Willis 1984) — that is, radical feminists believe that the cause of gender inequality is that society is a patriarchal system of relationships that produces a male supremacy that oppresses women. Liberal feminism focuses on women's ability to maintain equality through their own actions and choices and is based on individualism (Gallagher 2004). Radical and liberal feminists also have contrasting standpoints on prostitution. The former consider that prostitution is a form of extortion of women by men and degrades women, so they believe that it should be abolished. On the other 
Table 1. Comparison of Anti-prostitution Laws

\begin{tabular}{l|l|l}
\hline Legal terms & Prostitution Prevention Act & \multicolumn{1}{|c}{ New Prostitution Acts } \\
\hline $\begin{array}{l}\text { Punishment of the } \\
\text { procurer }\end{array}$ & $\begin{array}{l}\text { Imprisonment for a minimum } \\
\text { of five years }\end{array}$ & $\begin{array}{l}\text { Neutral, value-free, and human- } \\
\text { rights-centered }\end{array}$ \\
\hline Fine & $\begin{array}{l}\text { Imprisonment for a maximum of } \\
\text { ten years }\end{array}$ \\
\hline $\begin{array}{l}\text { Punishment of the } \\
\text { client }\end{array}$ & $\begin{array}{l}\text { Imprisonment for a maximum } \\
\text { of one year or fines of up to } \\
\text { KRW3,000,000 } \\
\text { (Police: lenient interpretation, } \\
\text { sometimes leads to dismissal) }\end{array}$ & $\begin{array}{l}\text { Confiscation of gains from } \\
\text { procuration }\end{array}$ \\
\hline $\begin{array}{l}\text { Victims of prostitution } \\
\text { (Police: unconditionally prosecute) }\end{array}$ & $\begin{array}{l}\text { Unconditionally punish the } \\
\text { sex seller. }\end{array}$ & $\begin{array}{l}\text { Acquit when prostitute was under } \\
\text { compulsion. }\end{array}$ \\
\hline $\begin{array}{l}\text { Protection of the } \\
\text { victims }\end{array}$ & None & $\begin{array}{l}\text { Victims can be admitted based on } \\
\text { the witness protection law. }\end{array}$ \\
\hline $\begin{array}{l}\text { Investigation Institute } \\
\text { support }\end{array}$ & None & $\begin{array}{l}\text { Police have the duty of rehabilitation } \\
\text { and emergency }\end{array}$ \\
\hline $\begin{array}{l}\text { Subsidization of } \\
\text { medical expenses }\end{array}$ & None & Founded the support plan \\
\hline
\end{tabular}

Source: Adapted from Ministry of Government Legislation 2004.

hand, "liberal feminists believe that every woman should be free to assert her personal rights, so they advocate that regulation of prostitution should be abolished as it infringes on a woman's professional rights" (Gallagher 2004).

Korea takes a regulatory position on prostitution from a radical feminist standpoint, where women's organizations have taken the initiative to legislate and execute policy. "In Korea, some advocates argue that there is no reason to restrict women's right to choose their profession, therefore sex should be recognized as a commodity" (Lee 2006; Hong 2008). However, this liberal viewpoint was not adopted into policy due to insufficient political support for it. This political situation was a result of a combination of the conservative political party's continuous defeat in two presidential elections and the general election in 2004, and the gradual expansion of women's participation in politics. In addition, the government's official activity on this issue increased with the establishment of the Ministry of Gender Equality in 2001 (renamed the Ministry of Gender Equality and Family in 2005). The Ministry and relevant institutions were comprised of NGOs' leading members and scholars whose views were oriented toward radical feminism. 
The New Prostitution Acts were established as a result of the government's ideology and radical feminists' demands. Some lawmakers in the opposition Grand National Party campaigned against the Acts, fearing unintentional side effects, but they did not prevail. "Even if a lawmaker was not a feminist, he or she would not object to the new laws. It was due to the fact that the opponents of the new laws were regarded as [opponents of] human rights" (Lee 2006). The new Acts were drafted with the intention of ensuring sexual ethics and guaranteeing the human rights of women.

\section{Chronology}

The New Prostitution Acts were not the first prostitution-related laws in Korea. The PPA, which was enacted in 1961, treated women who sold their favors solely as the object of punishment. There was a fundamental problem with this piece of legislation, as it did not punish the men buying the favors. In 1995, the PPA was revised substantially to adopt a dual punishment approach. Nevertheless, there were criticisms that even the revised Act could not reduce the spread of prostitution. In 2001, the Ministry of Gender Equality and the Ministry of Justice prepared to enact the PPA as a preventive step to curb prostitution.

The impetus to the enactment of the New Prostitution Acts was the conflagration that occurred at the brothels in Goonsan in Junbook province in September 2000. Five locked-in prostitutes died as a result of this disaster, which brought public attention to the slave-like situation of sex workers.

In February 2001, the Korea Alliance of Women's Organizations launched a new citizens' campaign for the protection of sex workers' human rights and to prevent a recurrence of the Goonsan tragedy. They also organized an experts' committee. In November 2001, the Punishment of Prostitution Brokerage Bill was submitted to the government by the Alliance. In January 2002, the Alliance formed a special committee to support the enactment of anti-prostitution laws.

In January 2002, another 14 sex workers died in Goonsan in another fire. This raised public concern to a critical level and prompted politicians, the relevant government ministries (the Ministry of Gender Equality and the Ministry of Justice), and NGOs to strengthen their resolve to enact the New Prostitution Acts. The PPA criminalized the act of prostitution regardless of the prostitute's will, therefore subjecting unwilling prostitutes to the same punishment as their clients. This discouraged the prostitutes from reporting their situation to the authorities. In addition, owing to the lack of rehabilitation services for women who once engaged in prostitution, many inevitably returned to the prostitution market.

The Ministry of Justice, the Ministry of Gender Equality, and the Office of the 
Table 2. Chronology

\begin{tabular}{l|l}
\hline \multicolumn{1}{c|}{ Time } & \multicolumn{1}{c}{ Event } \\
\hline 1961 & Prostitution Prevention Act (PPA) enacted. \\
\hline January 2000 & $\begin{array}{l}\text { Formation of public opinion for the revision of the PPA by the Jongam } \\
\text { District Chief, Kim Kangja }\end{array}$ \\
\hline September 2000 & Five sex workers died in a fire at Daemyung-dong brothel, Goonsan. \\
\hline January 2001 & Preparation for the amendment to the PPA. \\
\hline February 2001 & $\begin{array}{l}\text { Alliance of Women's Organizations launched a citizens' campaign for the } \\
\text { enactment of anti-prostitution legislation. }\end{array}$ \\
\hline November 2001 & Bill submitted by three members of the National Assembly. \\
\hline January 2002 & $\begin{array}{l}\text { Alliance of Women's Organizations formed the Special Committee for the } \\
\text { Enactment of the Anti-Prostitution Act }\end{array}$ \\
\hline January 2002 & Fourteen sex workers died in a fire at Gaebok-dong brothel, Goonsan. \\
\hline July 2002 & The New Prostitution Acts were proposed in the National Assembly. \\
September 2002 & $\begin{array}{l}\text { The Anti-Prostitution Project Team was founded in the Prime Minister's } \\
\text { Office. }\end{array}$ \\
\hline June 2003 & The National Assembly approved the New Prostitution Acts. \\
\hline March 2004 & The Acts entered into force. \\
\hline September 2004 & Brothels were subjected to intensive police crackdowns. \\
\hline September- \\
October 2004
\end{tabular}

Source: Adapted from Mok and Hong 2006.

Prime Minister organized an anti-prostitution planning committee in the Office of the Prime Minister for the purpose of launching the anti-prostitution policy. The Acts were passed by the National Assembly in March 2004 and entered into force in September. Shortly thereafter, the government authorized the police to carry out crackdowns at brothels.

\section{CHANGES AFTER THE NEW LAW}

\section{Changes Among Brothels and Sex Workers}

According to the Ministry of Gender Equality and Family, the number of brothels in Korea was about 1,700 in 2004 but decreased to fewer than 1,000 during the three years after the New Prostitution Acts came into effect. 
Table 3. Number of Brothels and Sex Workers in Korea

\begin{tabular}{l|c|c|c|c|c}
\hline & September 2004 & May 2006 & change & May 2007 & change \\
\hline Brothels & 1,679 & 1,097 & $-34.6 \%$ & 992 & $-9.6 \%$ \\
\hline Sex workers & 5,567 & 2,663 & $-52 \%$ & 2,523 & $-5.5 \%$ \\
\hline $\begin{array}{l}\text { Other types of } \\
\text { commercial sex shops }\end{array}$ & $\begin{array}{c}5,000 \\
\text { (estimate) }\end{array}$ & & & $\begin{array}{c}10,000 \\
\text { (estimate) }\end{array}$ & \\
\hline
\end{tabular}

Source: National Police Agency 2007.

\section{Changes in the Numbers of STD Patients}

The New Prostitution Acts came into effect on 23 September 2004. The trend for the infection rates of various STDs between 2001 and 2007 are shown in figures 1-5.

The occurrence of syphilis decreased sharply but temporarily after the implementation of the Acts. But after that, the number of cases increased at a steady rate up to July 2007. A possible reason for the sudden decrease in cases could be that it became difficult to maintain large-scale brothels ${ }^{1}$ in Seoul which were the target of crackdowns by the authorities. ${ }^{2}$

Gonorrhea had been decreasing steadily even before the New Prostitution Acts went into effect. According to the World Health Organization, this decrease in gonorrhea is the prevailing tendency in the world. One possible reason for it could be that the symptoms of gonorrhea are the same as the symptoms of nongonococcal urethritis. In many cases, gonorrhea patients are infected with nongonococcal urethritis as well. Gonorrhea is easier to diagnose than other STDs, and it is also easier to treat. For that reason, when a patient is infected with urethritis, doctors first check for the gonococcus and prescribe medicines for gonorrhea, so they sometimes miss the symptoms for nongonococcal urethritis. But in the latter case, it is difficult to find and treat the virus. Other viruses conceal themselves after gonorrhea treatment (Shin and Kim 2001).

The number of genital herpes and condyloma accuminata patients started to increase right after the implementation of the New Prostitution Acts, and the levels

1. The targets were the old large-scale brothel towns such as Yongsan, Chungryang-ri, and Mia-ri. Many sex workers in these areas soon left. The infection pathway of STDs through sex workers who were under the supervision of the sanitary authority prior to the New Prostitution Acts could not be followed up any more.

2. Syphilis has special characteristics compared with other sexually transmitted diseases. The incubation period is relatively long (three weeks to three months). It is a serious matter if it is not diagnosed immediately and can be fatal. Everyone associated with an infected patient has to have medical treatment. A fetus can also be infected. 
Figure 1. Cases of Syphilis

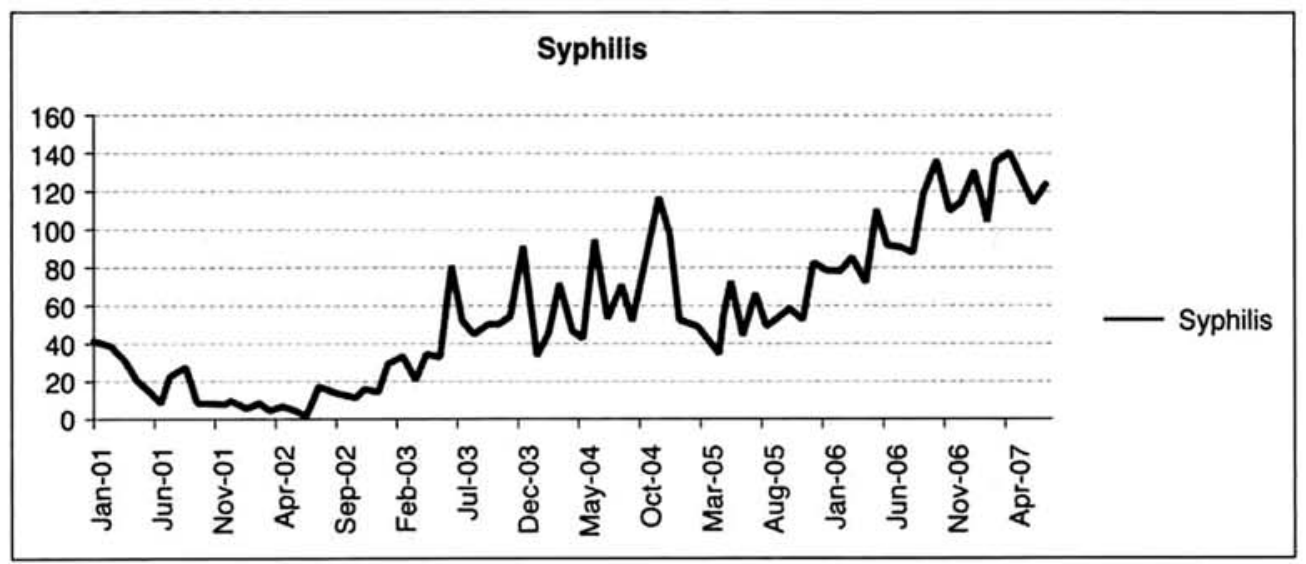

Source: Korea Centers for Disease Control and Prevention.

Figure 2. Cases of Gonorrhea

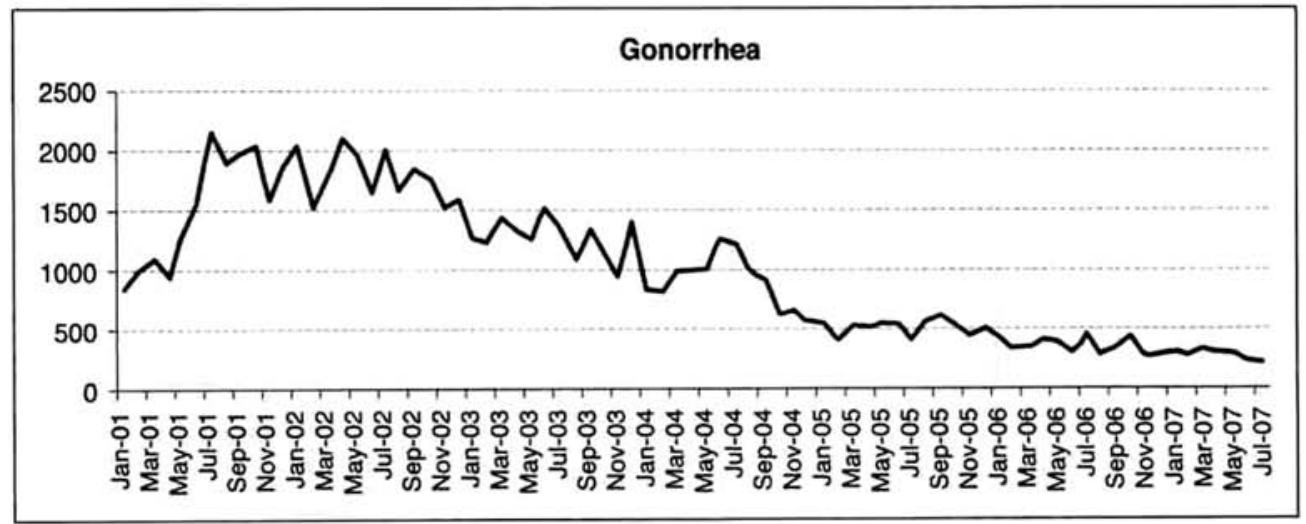

Source: Korea Centers for Disease Control and Prevention.

have stayed high up to the present. The number of chlamydia patients fluctuated widely, but has recently been increasing. ${ }^{3}$

One possible factor that could explain the upward trend in the number of STD infections shortly after the implementation of the New Prostitution Acts is that condom use decreased once police began to enforce the anti-prostitution policy. When

3. We excluded nongonococcal urethritis from this study although it is reported in the Standard Detecting System, because it is taken from the chlamydia virus to a great degree. The trend in the number of new patients is similar to that for chlamydia. 
Figure 3. Cases of Genital Herpes

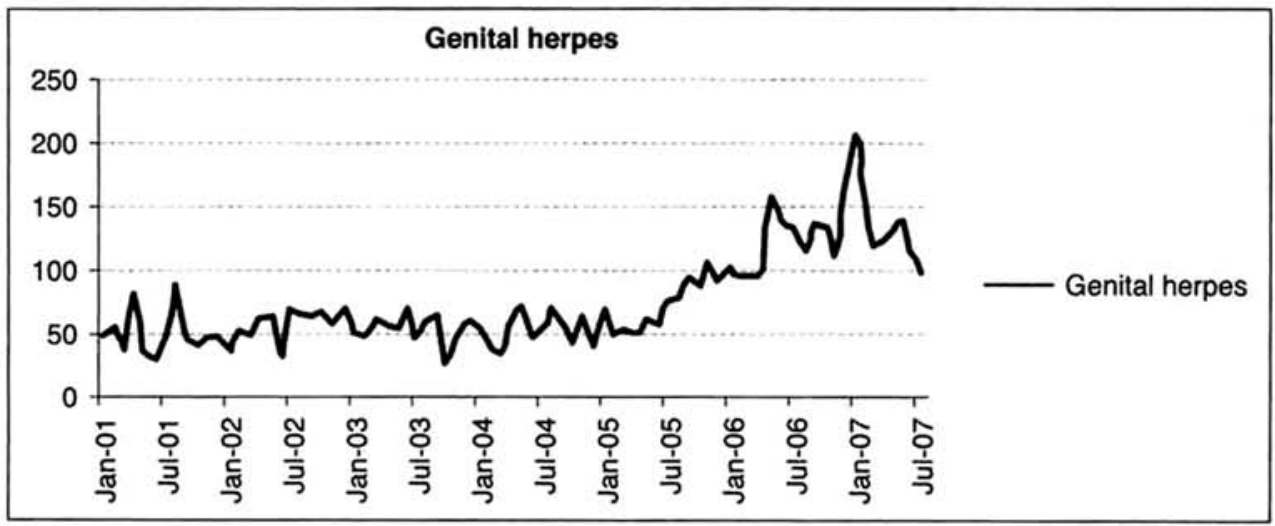

Source: Korea Centers for Disease Control and Prevention.

Figure 4. Cases of Condyloma Accuminata

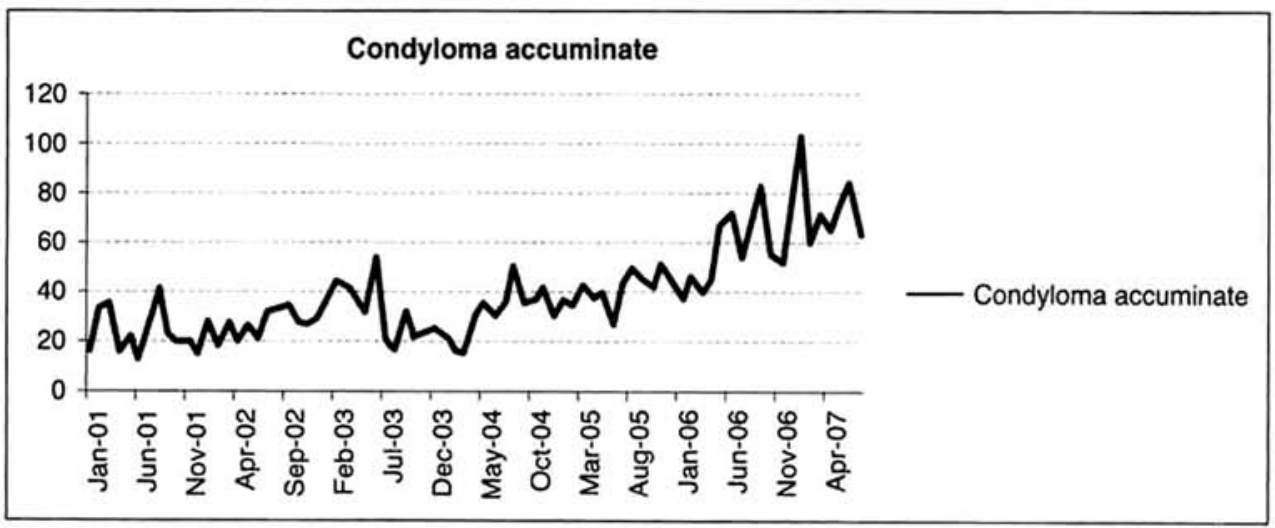

Source: Korea Centers for Disease Control and Prevention

police crack down on a prostitution site, sperm and condoms can be used as evidence of a sexual act (Kukmin ilbo 2007). Instances have been reported where, because no condoms were found, the police did not have adequate legal grounds to treat the person as a suspect. After the New Prostitution Acts went into effect, prostitution often occurred without condoms, so that if the police unexpectedly arrived, there would be no evidence.

Sales of condoms by the vendor with the largest market share in Korea ${ }^{4}$ rapidly decreased after the New Prostitution Acts were implemented (from KRW1,230,000,000

4. UNIDUS has 65 percent of condom sales in Korea. 
Figure 5. Cases of Chlamydia

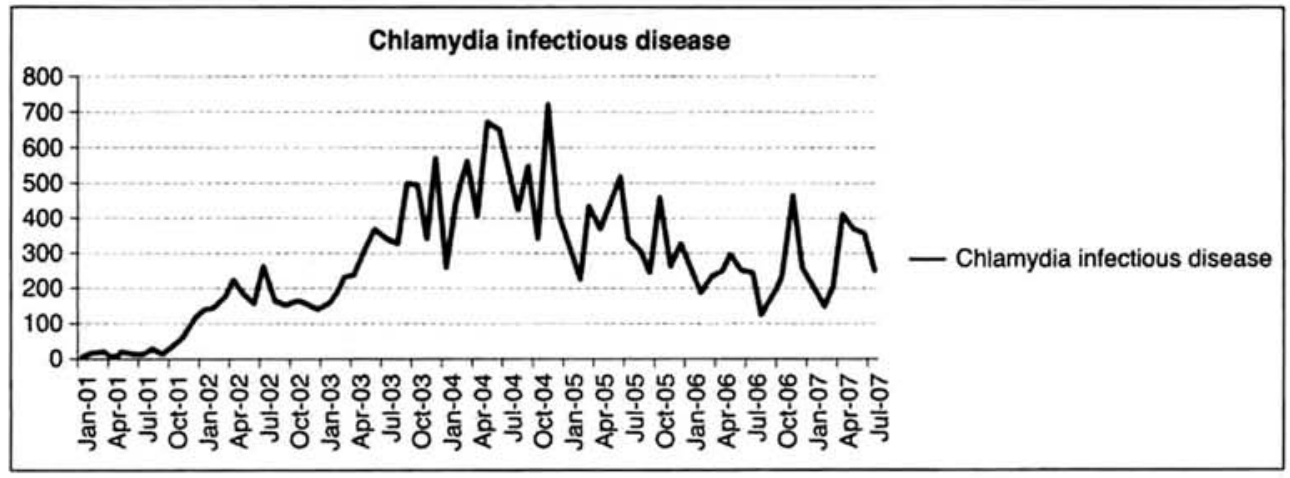

Source: Korea Centers for Disease Control and Prevention

in the third quarter of 2004 to KRW730,000,000 in the fourth quarter). In the first quarter of 2005, when the police crackdowns were most active, the sales of condom dropped again (KRW660,000,000). After that, sales recovered only partially.

\section{Preventing the Spread of STDs through Prostitution}

Generally, the government is unable to regulate or control the spread of STD infections through private relationships such as from husband to wife or girlfriend to boyfriend. However, prior to the New Prostitution Acts, the government could partially regulate and prevent STD infections acquired through prostitution by regularly monitoring the sexual health of prostitutes and collecting data on STD infections for scientific analysis.

At present, however, it is hard to control the spread of STDs through prostitution because the brothels have disappeared and the prostitutes cannot be traced. In addition, police crackdowns have discouraged the use of condoms, which interferes with an effective method of controlling the incidence of STDs.

\section{CONCLUSION}

The New Prostitution Acts, which were created with the good intentions of protecting sexual morality and human rights, also created unintended negative consequences, interfering with established methods of tracing STDs and weakening the incentive for condom wearing.

One additional issue remains to be explained. This research does not show the 
direct causal relationship between the policy and STDs. In analyzing the anti-prostitution policy, we have limited ourselves to analyzing the growth of STD infections after the implementation of the New Prostitution Acts. Nevertheless, this research could be significant in that it takes notice of the unintended effects of the Acts. Most research relating to the Acts has been concerned only with implementation failures and the effectiveness of durability plans (Kwon 2007; Kim 2006) or with legal and political aspects of the policy-making process (Mok and Hong 2006; Won and Park 2006). This study highlighted the importance of policy analysis and policy as its own cause through considering the negative effects which were unanticipated and unintended by the policy makers.

Up to now, we have looked at the unanticipated effects of the anti-prostitution laws. In other instances, policy makers have made attempts to correct the undesirable effects of anti-prostitution policy. However, in our opinion that is a mistake, because although the anti-prostitution policy may have good intentions, it restricts the property rights of the actors, in the sense of causing them a financial loss. To mitigate that loss, the actors maneuver their way around the law, and rarely do they just accept the government's policy. When past mistakes are repeated, and the general public repeatedly becomes interested in the policy only to be disappointed, people's confidence in the government can become undermined.

\section{REFERENCES}

Choi, J. H., I. C. Jeung, Y. G. Pak, and D. C. Park. 2007. Prevalence and risk factors of chlamydia trachomatis and neisseria gonorrhea among Korean women. Korean Journal of Obstetrics and Gynecology 50(12): 1739-46.

Clarkson, F. A. 1939. History of prostitution. The Canadian Medical Association Journal 41(3): 296-301.

Conner, S. P. 1989. Politics, prostitution, and the pox in revolutionary Paris, 17891799. Journal of Social History 22(4): 713-34.

Gallagher, S. K. 2004. Where are the antifeminist evangelicals? Evangelical identity, subcultural location, and attitudes toward feminism. Gender and Society 18(4): 451-72.

Hayek, F. A. von. 1945. The road to serfdom. Chicago: The University of Chicago Press.

Hong, J. H. 2008. Theory and practice on legal policy. Seoul: Bobmunsa.

Kim, E. K. 2006. A survey of prostitution offenders enrolled in the John School Diversion Program. Criminal Policy 18(2): 149-79. 
Kivingston, J., S. Day, and H. Ward. 2000. Prostitution policy in Europe: A time of change? Feminist Review 67(Spring): 78-93.

Korea Center for Disease Control and Prevention. 2007. Sentinel surveillance, http:// stat.cdc.go.kr/Sentinel/Venereal/Venereal_Location.aspx (accessed 1 August 2007).

Kukmin ilbo. 2007. Kukinews, 3 March 2007. http://www.kukinews.com/news/article/ view.asp?page $=1 \& \mathrm{gCode}=$ soc $\&$ arcid $=0920467511 \&$ code $=41121111$ (accessed 7 September 2007).

Kwon, O. M. (2004). The consideration about prostitution special law. Law Review 17:187-209.

Kwon, Y. S. 2007. The empirical study on the implemental effectiveness of the antiprostitution policy. Korean Society and Public Administration 18(1): 221-41.

Lasswell, H. 1971. A preview of policy sciences. New York: American Elsevier.

Lee, E. H., and J. K. Kim. 2006. Laws and policies surrounding prostitution in Europe. Seoul: Korea Legislation Research Institute.

Lee, H. W. 2007. Unintended consequences as the object of policy analysis. 2007 BK21 GSPA International Conference, 385-97.

Lee, I. H. 2003.The Korean War and expansion of women's labor. Studies of Korean History 14(1): 251-78.

Lee, J. S. 2006. The Anti-Prostitution Act on the economic perspective. Seoul: Korea Economic Research Institute.

Merton, R. K. 1936. The unanticipated consequences of purposive social action. American Sociological Review 1(6): 894-904.

Ministry of Government Legislation. 2004. Legislation information service, 2004, http://www.klaw.go.kr (accessed 30 August 2007).

Mok, J. H., and S. G. Hong. 2006. The case study on the anti-prostitution policy. The Korean Public Administration Study 15(1): 237-62.

National Police Agency. 2007. Reporting material 2007 submitted to National Assembly inspection of the administration. Seoul: National Police Agency.

Outshoorn, J., ed. 2004. The politics of prostitution. Cambridge: Cambridge University Press.

Park, J. S. 1996. Power and prostitution. Seoul: Ingansarang.

Richards, D. A. J. 1979. Commercial sex and the rights of the person: A moral argument for the decriminalization of prostitution. University of Pennsylvania Law Review 127(5): 1195-1287.

Shin, Y. I., and J. H. Kim. 2001. An epidemiological evaluation on the sexual partners of male patients with sexually transmitted disease. The Korean Journal of Dermatology 39(11): 1253-58. 
Trumbach, R. 1991. Sex, gender, and sexual identity in modern culture: Male sodomy and female prostitution in enlightenment London. Journal of History of Sexuality 2(2): 186-203.

Walkowitz, J. R. 1980. The politics of prostitution. Sign 6(1): 123-35.

Won, S. Y., and Park, J. K. 2006. The possibility of gender governance? A case study for the APPPV. Korean Women's Studies 22(4): 85-124.

Wildavsky, A. B. 1979. Speaking truth to power: The art and craft of policy analysis. Boston: Little Brown and Company.

Willis, E. 1984. Radical feminism and feminist radicalism. Social Text 9/10 (Spring/ Summer): 91-118.

Woo, M. S. 2006. Neo-liberal globalization and women's labor: Focusing on women's labor market participation in Korea. Yonsei University Social Science Research 27(1): 29-53.

World Health Organization. 2007. Global health atlas, http://www.who.int/globalatlas/ includeFiles/generalIncludeFiles/listInstances.asp (accessed 7 September 2007). 